\title{
A Study on the Level of Awareness of Overseas Filipino Workers (OFWS) At Tripoli, Libya on the Myths \& Facts on Corona Virus (Covid - 19): Basis for Program Planning
}

\author{
Maria Cristina Arboleda-Tinay ${ }^{1}$, Charge` d' Affaires en pied, Elmer G. Cato ${ }^{2}$, Dr. Ebtisam Ayad \\ BenOmran ${ }^{3}$, Evelyn Macasieb, RN, MSN ${ }^{4}$, Leonora Tilda Lesaca, RN, MN ${ }^{5}$, Lamour Laureta, RN, RM, MSN

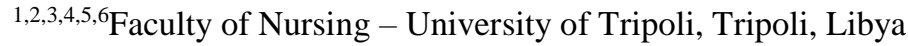

\begin{abstract}
The study aimed to determine the level of awareness of Overseas Filipino Workers (OFWs) of Tripoli, Libya on the myths \& facts on corona virus (COVID - 19). Specifically, this study answered the following questions:1) What are the Demographic Profile of the respondents in terms of Gender, Educational Background and Occupational Background?? 2) What are the Overseas Filipino Workers level of awareness on the myths \& facts on corona virus (COVID-19)? 3) Based on the results of the study, what measures can be formulated to increase the level of awareness of the Overseas Filipino Workers on corona virus (COVID-19)? The findings that the researcher was able to extract from the study were: 1) the frequency and percentage of the Overseas Filipino Workers demographic profile in terms of Gender, shows that female are mostly dominant which is 29 or $66.25 \%$ while male is 17 or $36.91 \%$. In terms of Educational Background, results reveals that mostly are on the College level which accounts to 29 or $63.04 \%$, Bachelor degree holder, 11 or $23.91 \%$, Masters 3 or $6.52 \%$, Doctorate 1 or $2.2 \%$ and College Undergraduate 2 or $4.3 \%$. Occupational Background of the respondents reveals that Predominantly, 26 or $56.5 \%$ belongs to the Health sector, Oil \& Gas 7 or $15.2 \%$, Education, 1 or $2.2 \%$, Others like those of the Embassies 8 or $17.4 \%$, Not applicable 4 or 8.7\%. There was a "Not Applicable" response as there were participants on the symposium who are dependents of the Overseas Filipino Workers and are not currently employed in Tripoli, Libya. 2) Detailed analysis of Table 3 reflecting the results of the frequency and percentage of the Overseas Filipino Workers level of awareness on the Facts and Myths of COVID-19 reveals that mostly $91.31 \%$ are aware of the facts on COVID-19, 5.70\% unaware and $2.98 \%$ undecided. Predominantly, $53.07 \%$ of the Overseas Filipino Workers are aware on Myths on COVID-19 as reflected on the "NO" responses on questions on MYTHS, however the $40.75 \%$ results on the "YES" responses showed only a difference of $12.32 \%$ which is quite alarming and $2.98 \%$ are undecided.3) The measures that could be formulated to increase the level of awareness of the Overseas Filipino Workers are to conduct information dissemination campaign through symposiums, research forums and the use of Information Education Campaign (IEC) materials. Based on these findings, the researcher was able to conclude that the Overseas Filipino Workers in Tripoli, Libya are aware of both the FACTS \& MYTHS on COVID-19, however, it is worthwhile to note that there is small difference in the figures reflected on the MYTHS aspect, thus there is still a need to correct these misconceptions so as to contribute on measures to end this pandemic.
\end{abstract}

KEY WORDS: Awareness, COVID-19, Myths \& facts

\section{INTRODUCTION}

A novel quote says "Then you will know the truth, and the truth will set you free". Human history is facing a very strange time struggling an invisible foe; the novel coronavirus disease-19 (COVID-19). ${ }^{(1)}$

The COVID-19 pandemic, also known as the coronavirus pandemic, is an ongoing pandemic of coronavirus disease 2019 (COVID-19) caused by severe acute respiratory syndrome coronavirus 2 (SARS-CoV-2). The disease was first identified in December 2019 in Wuhan, China. The World Health Organization declared the outbreak a Public Health Emergency of International Concern on 30 January 2020 and a pandemic on 11 March 2020. As of 25 September 2020, more than 32.2 million cases have been reported in 188 countries and territories, resulting in more than 983,000 deaths; more than 22.2 million people have recovered. 


\section{International Journal of Current Science Research and Review}

ISSN: 2581-8341

Volume 04 Issue 08 August 2021

DOI: 10.47191/ijcsrr/V4-i8-10, Impact Factor: 5.825

IJCSRR@ 2021

Www.ijcsrr.org

The disease spreads between people most often when they are physically close. It spreads very easily and sustainably through the air, primarily via small droplets or particles such as aerosols, produced after an infected person breathes, coughs, sneezes, talks or sings. It may also be transmitted via contaminated surfaces, although this has not been conclusively demonstrated. It can spread for up to two days prior to symptom onset, and from people who are asymptomatic. People remain infectious for 7-12 days in moderate cases, and up to two weeks in severe cases.

Common symptoms include fever, cough, fatigue, shortness of breath or breathing difficulties, and loss of smell. Complications may include pneumonia and acute respiratory distress syndrome. The incubation period is typically around five days but may range from one to 14 days. There are several vaccine candidates in development, although none have completed clinical trials to prove their safety and efficacy. There is no known specific antiviral medication, so primary treatment is currently symptomatic.

Recommended preventive measures include hand washing, covering mouth when coughing, social distancing, wearing a face mask in public, disinfecting surfaces, ventilating and air-filtering, and monitoring and self-isolation for people who suspect they may be infected. Authorities worldwide have responded by implementing travel restrictions, lockdowns, workplace hazard controls, and facility closures to slow the spread of the disease. Many places have also worked to increase testing capacity and trace contacts of the infected. ${ }^{(2)}$

The pandemic has caused global social and economic disruption, including the largest global recession since the Great Depression. According to estimations, up to 100 million people have fallen into extreme poverty and global famines are affecting 130 million people. It has led to the postponement or cancellation of sporting, religious, political, and cultural events, widespread supply shortages exacerbated by panic buying, and decreased emissions of pollutants and greenhouse gases. Educational institutions have been partially or fully closed, with many switching to online schooling. Misinformation about the virus has circulated through social media and mass media. There have been many incidents of xenophobia and racism against Chinese people and against those perceived as being Chinese or as being from areas with high infection rates.

The impact of the coronavirus outbreak was worldwide. The outbreak is a major destabilising threat to the global economy. Lloyd's of London has estimated that the global insurance industry will absorb losses of US $\$ 204$ billion, exceeding the losses from the 2017 Atlantic Hurricane season and 9/11, suggesting the COVID-19 pandemic will likely go down in history as the costliest disaster ever in human history.

Tourism is one of the worst affected sectors due to travel bans, closing of public places including travel attractions, and advice of governments against travel. Numerous airlines have cancelled flights due to lower demand, and British regional airline collapsed. The cruise line industry was hard hit, and several train stations and ferry ports have also been closed. International mail between some countries stopped or was delayed due to reduced transportation between them or suspension of domestic service.

The retail sector has been impacted globally, with reductions in store hours or temporary closures. Shopping mall operators around the world imposed additional measures, such as increased sanitation, installation of thermal scanners to check the temperature of shoppers, and cancellation of events. The economic impact and mass unemployment caused by the pandemic has raised fears of a mass eviction crisis. The outbreak has been blamed for several instances of supply shortages, stemming from globally increased usage of equipment to fight outbreaks, panic buying (which in several places led to shelves being cleared of grocery essentials such as food, toilet paper, and bottled water), and disruption to the factory and logistic operations. The spread of panic buying has been found to stem from perceived threat, perceived scarcity, fear of the unknown, coping behaviour and social psychological factors (e.g. social influence and trust). The technology industry, in particular, has warned of delays to shipments of electronic goods. According to the WHO director-general Tedros Adhanom, demand for personal protection equipment has risen a hundredfold, leading to prices up to twenty times the normal price and also delays in the supply of medical items of four to six months. It has also caused a shortage of personal protective equipment worldwide, with the WHO warning that this will endanger health workers. The pandemic has disrupted global food supplies and threatens to trigger a new food crisis.

By March 2020, across the world and to varying degrees, museums, libraries, performance venues, and other cultural institutions had been indefinitely closed with their exhibitions, events and performances cancelled or postponed. In response there were intensive efforts to provide alternative services through digital platforms. 


\section{International Journal of Current Science Research and Review}

ISSN: 2581-8341

\section{Volume 04 Issue 08 August 2021}

DOI: 10.47191/ijesrr/V4-i8-10, Impact Factor: 5.825

Due to this pandemic world facing many new deaths every day, even today the rate of the death increases across countries is due to panic and following the myths. With every global crisis comes an onslaught of conjecture and conspiracy theories, and coronavirus is no different. Hence it is important to know the truth and make the human minds free. Hence the review describes about the myths and real facts of covid19. ${ }^{(3)}$

We, as one of the Overseas Filipino Workers here in Libya believes for the need for continued access to research and learning. It has never been far more important. At this juncture, we, in the academe recognize our role in this, thus we bent on the study entitled "A Study on the Level of Awareness of Overseas Filipino Workers (OFWs) on the Myths \& Facts on Corona Virus (COVID-19)".

\section{METHODS}

This study employed the Descriptive Normative Survey method of research. "The study made used of structured questionnaire as an instrument utilizing closed ended questions. The data will be treated statistically using the frequency and percentage. The study is limited to Overseas Filipino Workers in Tripoli, Libya who participated in the recently concluded symposium conducted by the Philippine Embassy, Tripoli, Libya in collaboration with the Professors from University of Tripoli, Libya. This is for the primary reason that at the start of pandemic coupled with the political unrest in the country, the only ones who responded to the invitation to participate in the symposium becomes part of the study sample. Convenience sampling was used to select the samples. The findings of this study will be utilized as baseline information as to the planning on what measures the Philippine Embassy could to help in addressing this pandemic of COVID-19.

The questionnaire to be used in the interview is composed of two (2) parts, the Overseas Filipino Workers demographic profile and the indicators on the Myths \& facts of COVID-19. Communication was sent to the Charge' d' Affaires en pied and Head of Mission of the Embassy of the Republic of the Philippines, Tripoli, Elmer G. Cato, to seek perusal for the conduct of the study. After the consent had been sought, the questionnaires was distributed to Overseas Filipino Workers during day of the symposium before the start of the activity so as not to affect the internal validity of the study. After the data collection, the data was treated statistically.

\section{RESULTS}

Detailed analysis of Figure 1 showing the frequency and percentage of the Overseas Filipino Workers demographic profile in terms of Gender, shows that female are mostly dominant which is 29 or $63.04 \%$ while male is 17 or $36.91 \%$.

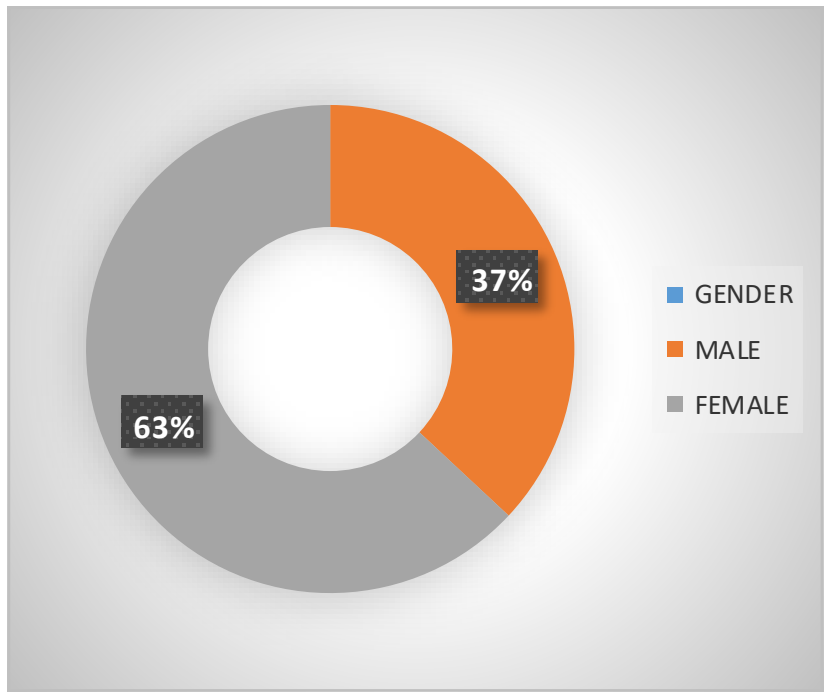

Figure 1 


\section{International Journal of Current Science Research and Review}

ISSN: 2581-8341

Volume 04 Issue 08 August 2021

DOI: 10.47191/ijesrr/V4-i8-10, Impact Factor: 5.825

IJCSRR@ 2021

www.ijcsrr.org

Cursory inspection of Figure 2 reflecting the results of frequency \& percentage of Educational Background reveals that mostly are on the College which accounts to 29 or $63.04 \%$, Bachelor degree holder, 11 or $23.91 \%$, Masters 3 or $6.52 \%$, Doctorate 1 or $2.2 \%$ and College Undergraduate 2 or $4.3 \%$.

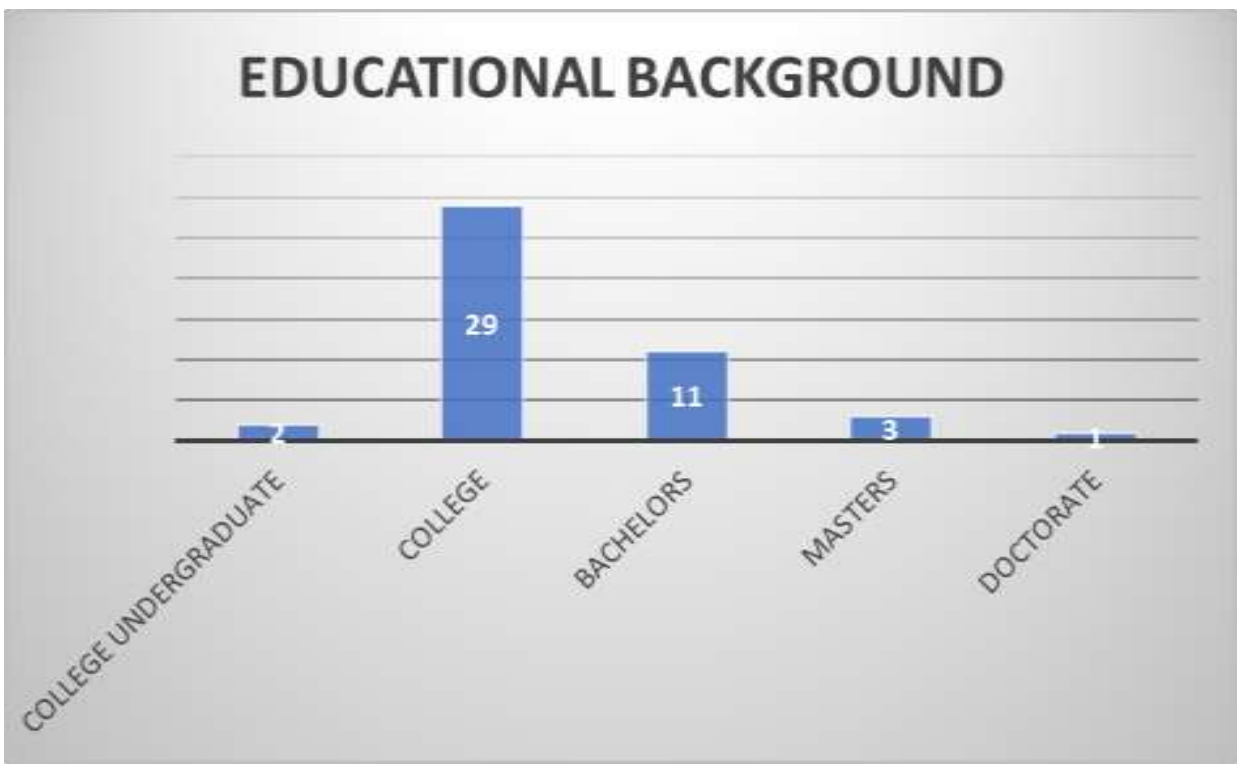

Figure 2

Figure 3 of the Occupational Background of the respondents reveals that Predominantly, 26 or $56.5 \%$ belongs to the Health sector, Oil \& Gas 7 or $15.2 \%$, Education, 1 or $2.2 \%$, Others like those of the Embassies 8 or $17.4 \%$, Not applicable 4 or $8.7 \%$. There was a "Not Applicable" response as there were participants on the symposium who are dependents of the Overseas Filipino Workers and are not currently employed in Tripoli, Libya.

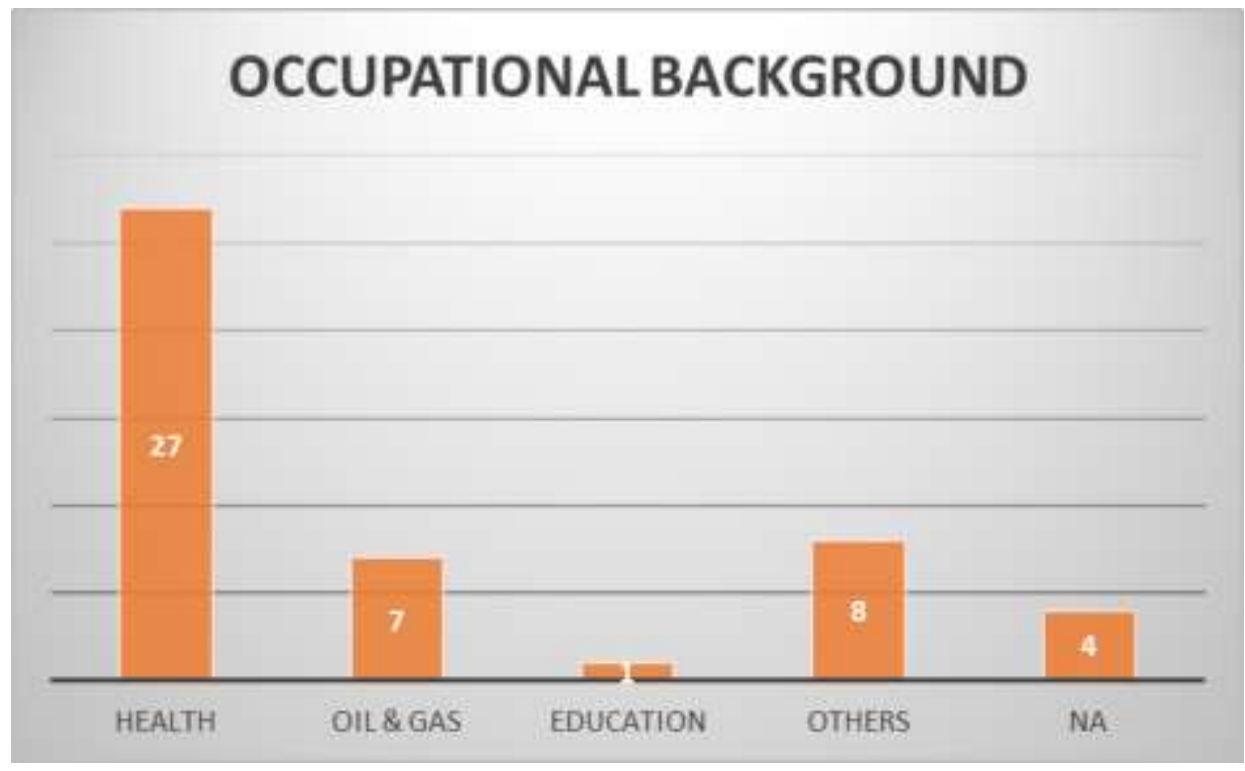

Figure 3 


\section{International Journal of Current Science Research and Review}

ISSN: 2581-8341

Volume 04 Issue 08 August 2021

DOI: 10.47191/ijesrr/V4-i8-10, Impact Factor: 5.825

IJCSRR@ 2021

www.ijcsrr.org

Detailed analysis of Table 3 reflecting the results of the frequency and percentage of the Overseas Filipino Workers level of awareness on the Facts and Myths of COVID-19 reveals that mostly $91.31 \%$ are aware of the facts on COVID-19, 5.70\% unaware and $2.98 \%$ undecided. Predominantly, 53.07\% of the Overseas Filipino Workers are aware on Myths on COVID-19 as reflected on the "NO" responses on questions on MYTHS, however the $40.75 \%$ results on the "YES" responses showed only a difference of $12.32 \%$ which is quite alarming and $2.98 \%$ are undecided.

Table 1. Frequency \& Percentage of Overseas Filipino Workers Level of Awareness on the Myths \& Facts of COVID - 19 $\mathrm{N}=46$

\begin{tabular}{|c|c|c|c|}
\hline INDICATOR & YES & $\mathrm{NO}$ & Undecided \\
\hline \multicolumn{4}{|l|}{ FACTS } \\
\hline 1. Are you aware of Coronavirus otherwise known as COVID-19? & $97.82 \%$ & - & $2.17 \%$ \\
\hline 2. Coronavirus is an infectious disease closely related to SARS virus. & $91.30 \%$ & $2.17 \%$ & $6.52 \%$ \\
\hline $\begin{array}{l}\text { 3. Coronavirus passes from one person to others via respiratory droplets } \\
\text { often during coughing or sneezing. }\end{array}$ & $95.65 \%$ & $4.34 \%$ & - \\
\hline $\begin{array}{l}\text { 4. Time from exposure to onset of symptoms is generally from 2-14 } \\
\text { days. }\end{array}$ & $97.82 \%$ & $2.17 \%$ & - \\
\hline $\begin{array}{l}\text { 5. Washing hands with soap and water or using alcohol-based hand rub } \\
\text { kills viruses. }\end{array}$ & $95.65 \%$ & $4.34 \%$ & - \\
\hline $\begin{array}{l}\text { 6. Maintaining at least } 1 \text { meter ( } 3 \text { feet) distance to anyone who is } \\
\text { coughing or sneezing prevents spread of coronavirus? }\end{array}$ & $82.60 \%$ & $13.04 \%$ & $4.34 \%$ \\
\hline $\begin{array}{l}\text { 7. Avoiding touching one's face are recommended to prevent the } \\
\text { disease. }\end{array}$ & $91.30 \%$ & $2.17 \%$ & $6.52 \%$ \\
\hline $\begin{array}{l}\text { 8. Does wearing of mask at crowded place is a must to prevent the } \\
\text { spread of coronavirus? }\end{array}$ & $78.3 \%$ & $17.39 \%$ & $4.34 \%$ \\
\hline TOTAL & $91.31 \%$ & $5.70 \%$ & $2.98 \%$ \\
\hline \multicolumn{4}{|l|}{ MYTHS } \\
\hline 9. Are hand dryers effective in killing the new coronavirus? & $34.78 \%$ & $60.86 \%$ & $4.34 \%$ \\
\hline $\begin{array}{l}\text { 10. Are thermal scanners effective in detecting people infected with the } \\
\text { new coronavirus? }\end{array}$ & $73.91 \%$ & $26.08 \%$ & - \\
\hline $\begin{array}{l}\text { 11. Can spraying alcohol or chlorine all over your body kill the new } \\
\text { coronavirus? }\end{array}$ & $52.17 \%$ & $45.65 \%$ & $2.17 \%$ \\
\hline 12. Can pets at home spread the new coronavirus? & $60.86 \%$ & $32.60 \%$ & $6.52 \%$ \\
\hline $\begin{array}{l}\text { 13. Do vaccine against pneumonia protect you against the new } \\
\text { coronavirus? }\end{array}$ & $34.78 \%$ & $58.69 \%$ & $6.52 \%$ \\
\hline 14. Can regularly rinsing your nose with saline help prevent infection? & $43.47 \%$ & $47.82 \%$ & $8.69 \%$ \\
\hline 15. Can eating garlic help prevent infection with the new coronavirus? & $26.08 \%$ & $69.56 \%$ & $4.34 \%$ \\
\hline $\begin{array}{l}\text { 16. Does putting on sesame oil block the new coronavirus from entering } \\
\text { the body? }\end{array}$ & $6.52 \%$ & $86.95 \%$ & $6.52 \%$ \\
\hline $\begin{array}{l}\text { 17. Are older and younger persons more susceptible to the new } \\
\text { coronavirus? }\end{array}$ & $65.21 \%$ & $23.91 \%$ & $10.86 \%$ \\
\hline $\begin{array}{l}\text { 18. Are antibiotics effective in preventing and treating the new } \\
\text { coronavirus? }\end{array}$ & $23.91 \%$ & $69.56 \%$ & $6.52 \%$ \\
\hline 19. Are there specific medicines to prevent or treat the new coronavirus? & $8.69 \%$ & $80.43 \%$ & $10.86 \%$ \\
\hline $\begin{array}{l}\text { 20. Will warmer spring temperatures and hot weather help stop the } \\
\text { coronavirus outbreak? }\end{array}$ & $58.69 \%$ & $34.78 \%$ & $6.52 \%$ \\
\hline TOTAL & $\mathbf{4 0 . 7 5 \%}$ & $\mathbf{5 3 . 0 7 \%}$ & $6.15 \%$ \\
\hline
\end{tabular}




\section{International Journal of Current Science Research and Review}

ISSN: 2581-8341

Volume 04 Issue 08 August 2021

DOI: 10.47191/ijcsrr/V4-i8-10, Impact Factor: 5.825

IJCSRR@ 2021

WWw.ijcsrr.org

\section{DISCUSSION}

Infodemic: "An over-abundance of information—-some accurate and some not—-that makes it hard for people to find trustworthy sources and reliable guidance when they need it." (WHO, 2020)

With an overwhelming amount of information online and media influencers promoting so-called 'cures' for coronavirus, it can be hard to decipher myth from fact. As scientists and researchers race to understand the novel coronavirus, the world faces a double threat: the spread of COVID-19, and the spread of misinformation around it. It may be overwhelming to digest all this new information and maybe even more difficult to understand fact from fiction. The results of this study proves that there are some misconceptions that needs to be addressed therefore thorough discussions on the Facts \&Myths on COVID 19 are presented. ${ }^{(4)}$

Among the Indicators on "Facts", Indicator \#8, "Does wearing of mask at crowded place is a must to prevent the spread of coronavirus" reveals the lowest frequency \& percentage of 78.3\% for "YES" responses with which it is striking to note that there is a significant number who are not aware of the importance of wearing a mask. There is clear evidence that masks help prevent the spread of COVID-19, including a recent study from our Health Affairs journal which found that state mask mandates led to a slowdown in the daily COVID-19 growth rate. Anyone over the age of 2 should wear a mask covering the mouth and nose when out in public — and maintain physical distance (of at least six feet) from others. Cloth and medical masks don't filter out small aerosolized droplets like N95 respirators do, but they are effective in blocking out larger respiratory droplets, which are currently considered the most frequent mode of transmission. Masks should always be worn in public, with one exception: when exercising. The World Health Organization actually advises that people not wear masks while exercising, as sweat will make it more difficult to breathe and spur the growth of microorganisms but exercisers should still be sure to practice social distancing. ${ }^{(5)}$

On the Myth aspect, Indicator \#10, Are thermal scanners effective in detecting people infected with the new coronavirus got the highest of $73.91 \%$. Thermal scanners are effective in detecting people who have a fever (i.e. have a higher than normal body temperature). They cannot detect people who are infected with COVID-19. There are many causes of fever. Call your healthcare provider if you need assistance or seek immediate medical care if you have fever and live in an area with malaria or dengue. ${ }^{(6)}$

Indicator \#17, Are older and younger persons more susceptible to the new coronavirus, reveals $65.21 \%$ of "YES" response which indicates that a lot believes that the said myth. While COVID-19 can be more dangerous in older people, anyone can get it including young people, some of whom become seriously ill. While we don't yet fully understand why some people get more serious symptoms, we do know that young people are more likely to develop serious symptoms if they have certain underlying health conditions, for example asthma, heart conditions or untreated HIV. Children are less likely to show severe signs of illness, anyone at any age can become infected, and some children have experienced serious and unusual symptoms. The Centers for Disease Control and Prevention recommend children 2 years and older should wear a cloth face covering in public, in addition to cleaning hands often and avoiding people who are sick. ${ }^{(7)}$

Indicator \#12, "Can pets at home spread the new coronavirus", shows a result of $60.86 \%$. Several dogs and cats (domestic cats and tigers) in contact with infected humans have tested positive for COVID-19. In addition, ferrets appear to be susceptible to the infection. In experimental conditions, both cats and ferrets were able to transmit infection to other animals of the same species. However, there is no evidence that these animals can transmit the disease to humans and spread COVID-19. COVID-19 is mainly spread through droplets produced when an infected person coughs, sneezes, or speaks. ${ }^{(6)}$

Indicator \#20, "Will warmer spring temperatures and hot weather help stop the coronavirus outbreak", COVID-19 can survive temperatures higher than $25 \mathrm{C}$. You can catch it no matter how sunny and warm it is. So, whatever the weather you should follow the official advice to protect yourself from the virus. ${ }^{(8)}$

Indicator \#11, "Can spraying alcohol or chlorine all over your body kill the new coronavirus" revels a result of 52.17\%. Do not under any circumstance spray or introduce bleach or any other disinfectant into your body. These substances can be poisonous if ingested and cause irritation and damage to your skin and eyes. Bleach and disinfectant should be used carefully to disinfect surfaces only. Remember to keep chlorine (bleach) and other disinfectants out of reach of children. ${ }^{(6)}$ 


\section{International Journal of Current Science Research and Review}

ISSN: 2581-8341

Volume 04 Issue 08 August 2021

DOI: 10.47191/ijcsrr/V4-i8-10, Impact Factor: 5.825

IJCSRR@ 2021

WWw.ijcsrr.org

It has been purported that one of the major take-home messages from the bizarre events of 2016 is that we are now living in a "post-truth" world. Indeed, that very phrase was dubbed the "word of the year" by Oxford Dictionaries, which defines it as "relating to or denoting circumstances in which objective facts are less influential in shaping public opinion than appeals to emotion and personal belief." Many of us will choose to fight against accepting the notion that we are entering a "post-truth" era. To fight that good fight, we must acknowledge that "truth" is an elusive concept requiring the analysis and application of factual information, and advocate for educational (and testing) approaches that will yield the educated citizenry. ${ }^{(9)}$

\section{CONCLUSIONS}

It can be said that the Overseas Filipino Workers in Tripoli, Libya who have attended the symposium are mostly aware of the facts on COVID-19 but there are high percentage of responses of "YES" on the myths which proves that there is a need to increase the level of awareness of the Overseas Filipino Workers on COVID-19. It is but recommended that information dissemination be done so as to provide measures to stop the spread of this pandemic and conducting symposiums, research forums and distribution of IEC materials could be the initial step on this endeavour.

\section{REFERENCES}

1. https://www.researchgate.net/publication/coronavirusdisease

2. Journal of Emerging Technologies and Innovative Research, April 2020, Vol 7, Issue 4.

3. https:// www.ncbi.nlm.nih.gov/pmc/articles

4. https://www.newyorker.com

5. https://www.projecthope.org/fact-or-fiction-6-myths-about-covid-19/08/2020/

6. https://www.who.int/emergencies/diseases/novel-coronavirus-2019

7. https://www.uchealth.com/en/media-room/covid-19/the-myths-and-facts-of-covid-19

8. https://www.hopkinsmedicine.org/health/conditions-and-diseases/coronavirus/2019

9. http://blogs.einstein.yu.edu/just-how-important-are-facts

Cite this Article: Maria Cristina Arboleda-Tinay, Charge`d'Affaires en pied, Elmer G. Cato, Dr. Ebtisam Ayad BenOmran, Evelyn Macasieb, RN, MSN, Leonora Tilda Lesaca, RN, MN, Lamour Laureta, RN, RM, MSN, (2021). A Study on the Level of Awareness of Overseas Filipino Workers (OFWS) At Tripoli, Libya on the Myths \& Facts on Corona Virus (Covid - 19): Basis for Program Planning. International Journal of Current Science Research and Review, 4(8), $940-946$ 